\title{
RECENZJE
}

MAGDALENA SZULC-BRZOZOWSKA ${ }^{\star}$ KATOLICKI UNIWERSYTET LUBELSKI JANA PAWŁA II

\section{Waldemar Czachur, Lingwistyka dyskursu jako integrujący} program badawczy

OFICYNA WYDAWNICZA ATUT, WROCŁAW 2020, s. 313

doi: http://dx.doi.org/10.31286/JP.101.3.11

Dyskurs jako pojęcie niedookreślone, z proweniencją filozoficzną, stanowi nie lada wyzwanie dla językoznawstwa zarówno pod względem stworzenia spójnej teorii, jak i metodologii badań oraz zintegrowania kategorii dyskursu. Stąd szereg dociekań, rozpraw naukowych, w których obliczu ktoś mógłby pochopnie powiedzieć o nowej monografii Waldemara Czachura: „To tylko kolejna publikacja na temat lingwistyki dyskursu. W jakim celu?". Cel został precyzyjnie sformułowany we wstępie, określony już w tytule jako: „ujęcie lingwistyki dyskursu jako zintegrowanego programu badawczego". Oznacza to odejście od traktowania lingwistyki dyskursu jako subdyscypliny lub działu językoznawstwa. Głównym celem monografii jest wprawdzie refleksja nad teoretycznymi, metodologicznymi i metodycznymi założeniami lingwistyki dyskursu, ale perspektywę tychże poszukiwań określa sposób projektowania przedmiotu, celu i procedury badawczej. Meritum definiowania lingwistyki dyskursu jako zintegrowanego programu badawczego przedstawione jest uzupełniająco na przykładach.

Wartością dodaną monografii jest odwołanie się zarówno do tradycji germanistycznej, jak i polonistycznej w kontekście rozwoju badań dyskursologicznych, zwłaszcza pod kątem włączenia kategorii dyskursu w istniejące programy badawcze.

Monografia składa się z sześciu rozdziałów. Pierwszy ma charakter wstępu, w którym omówiono koncepcję pracy.

Tematem drugiego, obszernego rozdziału są najpierw założenia dotyczące charakteru dyskursu, w tym aspekt użycia języka i znaczeń zbiorowych, hasłowo określony przez Autora jako „język w użyciu”. Przywołuje on teoretyczne podstawy lingwistyki dyskursu zakorzenione w filozofii (Wilhelm von Humboldt, Karl Bühler, Ludwig Wittgenstein, Bronisław Malinowski, Ernst Cassirer), które w późniejszym okresie znalazły swoje odbicie głównie w paradygmacie pragmalingwistycznym i kognitywistycznym. Chodzi tu przede wszystkim o takie elementy tych teorii jak: odzwierciedlenie sposobu postrzegania i konceptualizacji rzeczywistości w języku oraz uwarunkowania użycia języka przez kulturę, które obejmują społeczno-kulturowy aspekt

* szulc@kul.pl, ORCID: oooo-00o3-3163-4279 
kształtowania znaczenia. Na uwagę zasługuje zgłębienie faktu, że modelowanie analizy lingwistycznej zarówno w odniesieniu do poprzedzającego owe paradygmaty strukturalizmu, jak i w nurcie poststrukturalistycznym przebiegało w kręgu germanistycznym i polonistycznym w sposób zróżnicowany. Autor przywołuje Tadeusza Milewskiego i Leona Zawadowskiego jako prekursorów nurtu poststrukturalistycznego w Polsce, równocześnie opisując ich koncepcje wskazuje na dwie perspektywy analizy językoznawstwa strukturalistycznego w Polsce, tj. z punktu patrzenia na (1) sposób modelowania języka jako przedmiotu badań oraz (2) modelowanie poziomów jego analizy. Bazując na teorii poznania Ludwika Flecka i dominującego w niej konceptu określonego tu jako kolektyw myślowy, uwzględniającego czynniki kulturowe i społeczne, Autor w sposób ukierunkowany i precyzyjny przedstawia rozwój badań nad językiem w użyciu, które przyczyniły się do powstania koncepcji dyskursu w językoznawstwie zarówno polonistycznym, jak i germanistycznym. Porównanie interlingwistyczne tychże nurtów trafia w sedno, pokazuje między innymi integrację kategorii dyskursu w lingwistyce, uwzględniając przy tym specyfikę warunków społeczno-politycznych. Czytelnik dowiaduje się, jak przebiegała ewolucja badań nad językiem w użyciu w lingwistyce polonistycznej, tj. począwszy od lingwistyki tekstu poprzez stylistykę, etnolingwistykę oraz lingwistykę kulturową aż po genologię lingwistyczną i mediolingwistykę. W tradycji germanistycznej Autor wskazuje na rozbieżność rozwoju lingwistyki w Republice Federalnej Niemiec (RFN) i w Niemieckiej Republice Demokratycznej (NRD) ze względu na odmienne uwarunkowania ideologiczne obu krajów. Słusznie też zauważa, że w RFN z uwagi na przeszłość związaną z narodowym socjalizmem w głównym nurcie utrzymywał się przez długie lata paradygmat strukturalistyczny, podczas gdy kontekst kulturowy nie był podejmowany, zaś w NRD, podobnie jak w Polsce, myślenie o języku w aspekcie kulturowym i funkcjonalistycznym oraz wpływy semiotyków, głównie ze Związku Socjalistycznych Republik Radzieckich (ZSRR), skierowały badania na inny tor. W lingwistyce germanistycznej rozwój badań nad językiem zainicjowała teoria aktów mowy i działania, następnie skoncentrowały się one na analizie konwersacji, stylistyce i lingwistyce tekstu. Lingwistykę mediów i kulturową zalicza Autor do „efektów zadomowienia się lingwistyki dyskursu".

Nowe spojrzenie na język, nowy styl myślenia (według terminologii L. Flecka), który akcentuje komunikowanie pomiędzy kolektywami, tworzenie znaczeń i sensów zbiorowych, a nawet rzeczywistości, jako paradygmat poststrukturalistyczny omawia Autor w końcowej części rozdziału. Również ten opis obejmuje dwie tradycje, polonistyczną i germanistyczną. Autor akcentuje, że nie chodzi tu o jedną spójną teorię języka, lecz zespół założeń o takim charakterze. Na plan pierwszy wysuwa kreatywną funkcję języka, konceptualizację rzeczywistości i jej kategoryzację na podstawie doświadczeń i wartości kolektywnych. Pozostając przy założeniach umiarkowanego realizmu ontycznego, umiarkowanego kognitywizmu i konstruktywizmu, umieszcza tezę o modelowaniu rzeczywistości w kontekście dyskursu jako kreowaniu pewnego obrazu rzeczywistości. Teza ta połączona jest z konstatacją, że zarówno znaczenia zbiorowe, jak i zbiorowe systemy przekonań są w dyskursie negocjowane w sposób świadomy. Koncepcję tę podpierają między innymi założenia etnolingwistyki lubelskiej, 
lingwistyki kognitywnej, w tym teorii ramy konceptualnej czy też teorii walki o władzę obecnej w dyskursie Michela Foucaulta.

Rozważania na temat paradygmatu poststrukturalistycznego prowadzą do istotnych, trafnie ujętych konkluzji, mianowicie: problematyczne stało się określenie granic językoznawstwa i pojawiła się konieczność dostosowania narzędzi badawczych do potrzeb określonych celów badawczych. Synkretyzm metodologiczny jest również wyzwaniem. W ramach podejścia integracjonistycznego eklektyzm miałby dotyczyć pytań badawczych, przedmiotów badań, łączenia metod, sposobu interpretacji i wyników badań (por. s. 105), nie tylko triangulacji metodycznej. Na pytanie o relację między lingwistką dyskursu a integracjonizmem dążącym do stworzenia spójnej, holistycznej teorii języka, która uwzględniałaby aspekty społeczne, polityczne, ideologiczne i kulturowe w projektowaniu przedmiotu badań i narzędzi badawczych, czytelnik znajduje odpowiedź w dalszej części monografii.

Rozdział trzeci traktuje o dyskursie jako przedmiocie badań lingwistycznych. W pierwszej kolejności omówiona jest koncepcja Michela Foucaulta, w której wyróżnione są elementy mające charakter stymulacyjny dla lingwistyki dyskursu, między innymi sprawczość dyskursu, konceptualizacja rzeczywistości poprzez język, konieczność uwzględnienia szeregu aspektów, takich jak władza, ideologia, procesy społeczne, wartości, język jako instrument władzy i wiedzy. Należy się zgodzić z konkluzją Autora, że teoria dyskursu M. Foucaulta i lingwistyka poststrukturalistyczna mają cechy wspólne, te zaś stanowią fundament rozwoju lingwistyki dyskursu. W dalszej części rozdziału przedstawiono główne sposoby modelowania pojęcia dyskursu w dotychczasowych badaniach $\mathrm{z}$ uwzględnieniem tradycji germanistycznej i polonistycznej. Dyskurs został naświetlony z różnych perspektyw, jako: (1) powiązane tematycznie teksty, (2) (medialna) seria działań komunikacyjnych, interakcja i praktyka społeczna, (3) wzorzec komunikacji społecznej, (4) selekcjonowanie wiedzy i proces negocjowania sensów zbiorowych. Kluczowe dla całości opracowania i sedna książki jest nakreślenie zróżnicowania relacji między poszczególnymi aspektami modelowania w zależności od sposobu projektowania badania. Na uwagę zasługuje też wywód odnoszący się do czynników warunkujących dyskurs oraz związku między dyskursem a znaczeniem. Tu przebija się teza o istocie dyskursu, w którym językowi można przypisać sprawczość tworzenia znaczeń. Punktem wyjścia do rozważań na temat relacji między dyskursem a kulturą, medium i praktykami komunikacyjnymi staje się stwierdzenie o wzajemnej zależności między umysłami uczestników a dyskursem jako miejscem powstawania wiedzy. W podsumowaniu znajdujemy holistyczną definicję dyskursu uwzględniającą warunkujące go czynniki oraz relacje pomiędzy nimi. Wpisuje się w nią dyskursywny obraz świata (Doś) jako kategoria analityczna.

Zaprezentowany w tym rozdziale przegląd stanowisk zawiera fragmenty polemiczne oraz elementy analizy połączonej z syntezą; w rezultacie uzyskujemy transparentną, ugruntowaną tezę o „znaczeniotwórczym potencjale” dyskursu oraz warunkujących go czynnikach.

Rozdział czwarty poświęcony jest włączeniu kategorii dyskursu do polonistycznej i germanistycznej tradycji metodologicznej. Opis nie wyczerpuje źródeł, ale - jak sam Autor zauważa jest nastawiony na analizę wybranych przykładów cechujących się integracyjnym charakterem, 
chociaż zróżnicowanych pod względem celów badania. Pochodzą one z krytycznej analizy dyskursu Siegfrieda Jägera, lingwistyki dyskursu Jürgena Spitzmüllera i Inga Warnkego, stylistyki dyskursu Bożeny Witosz oraz mediacyjnej analizy dyskursu Tomasza Piekota. Przykłady reprezentują dwa różne podejścia do integrowania kategorii dyskursu, tj. tworzenia nowej metodologii (T. Piekot, S. Jäger, J. Spitzmüller, I. Warnke) i uzupełnienia istniejącej metodologii o kategorię dyskursu (B. Witosz).

Piąty rozdział, stanowiący sedno monografii, opisuje założenia lingwistyki stosowanej zdefiniowanej jako program badawczy, rozumianej nie jako metodologia lub perspektywa badawcza, lecz jako rama spajająca różne perspektywy teoretyczno-metodologiczne. W świetle poprzedzających wywodów integracjonizm lingwistyki dyskursu jawi się jako konieczność i wyzwanie. Manifestuje się w obszarze projektowania przedmiotu badań, celu poznawczego i procedury poznawczej. Autor podkreśla relację zwrotną między projektowaniem dyskursu jako przedmiotu badań a ich integralnością. Przy projektowaniu dyskursu jako przedmiotu badań wyróżnia perspektywy poznawczą i ontyczną. W odniesieniu do tej pierwszej nazywa subdyscypliny i narzędzia analityczne, które mogą wejść w kooperację z lingwistyką dyskursu. W kontekście drugiej opisuje komplementarne względem siebie wymiary dyskursu: instytucjonalny, tematyczny i modalny/ideologiczny. W dalszej części Autor omawia projektowanie procedury badawczej, jej etapy i główne narzędzia analityczne. Ramą opisu instrumentów są przedstawione wcześniej modele, dodatkowo uwzględniono innych badaczy i ich najnowsze opracowania. Ujęcie tematu należy traktować jako propozycję, ale również jako dowód na to, że integracjonizm oraz triangulacja teoretyczna i metodyczna są odpowiedzią na potrzeby lingwistyki poststrukturalistycznej. Całość wywodu wieńczy studium przypadku, w którym tkwi potencjał dydaktyczny monografii.

Rozdział szósty zawiera podsumowującą refleksję nad dyskursem.

Zaletą monografii jest wnikliwa analiza problematyki lingwistycznych badań nad dyskursem w tradycjach polonistycznej i germanistycznej. Autor w sposób koherentny i transparentny prowadzi wywód zmierzający do przedstawienia i niejako legitymizacji lingwistyki dyskursu jako programu badawczego. Odwołanie do obu tradycji jest niezaprzeczalnym walorem nie tylko z powodu ogólnego poszerzenia ujęcia tematu, lecz również z uwagi na aspekt komparatystyczny oraz pogłębienie ramy teoretyczno-metodologicznej badań dyskursologicznych w nurcie germanistycznym dzięki perspektywie polonistycznej i odwrotnie. Ma to wyjątkowe znaczenie w obliczu polskojęzyczności monografii, dzięki której dostęp do wiedzy o badaniach germanistycznych zyskują czytelnicy nieznający języka niemieckiego.

Dlatego za szczególnie cenne uważam analizę podobieństw i różnic między teoriami i podejściami w ujęciu polonistycznym i germanistycznym sięgającymi paradygmatu strukturalistycznego i wychodzącymi poza niego, w tym pomiędzy programami badawczymi o charakterze integrującym kategorię dyskursu, oraz umieszczenie ich w kontekście wyzwań lingwistyki poststrukturalistycznej oraz badań inter- i transdyscyplinarnych.

Książka jest godna polecenia wszystkim tym, którzy szukają nie tylko (choć przede wszystkim) teoretyczno-metodologicznej syntezy lingwistyki dyskursu w postaci programu badawczego, ale również analizy badań nad dyskursem ukierunkowanych na taką syntezę i przeglądu 
stanowisk na ten temat. Przejrzysta i uporządkowana struktura książki, liczne komentarze podsumowujące wywody pozwalają nawet na czytanie wybiórcze, a studium przypadku zachęca do sięgania po lekturę nawet mniej profesjonalnych niż badacz językoznawca czytelników (np. studentów). Należy ostatecznie podkreślić, że systematyzujący i „projektujący” (s. 14) charakter monografii zarówno w aspekcie teoretycznym, jak i metalingwistycznym stanowi jej niepodważalny atut, zwłaszcza w obliczu gąszczu teorii, metodologii, metod badawczych odnoszących się do badań nad dyskursem. W związku z tym - podążając za intencją Autora recenzowana książka może stanowić fundament rozwoju zaproponowanego programu badawczego lub/i tworzenia teorii dyskursywnych i kulturowych języka, a zatem być niejako praktycznym przewodnikiem w obszarze badań nad dyskursem, zwłaszcza lingwistyki dyskursu. 